\title{
PARTISIPASI PEREMPUAN DALAM MENINGKATKAN KESEJAHTERAAN KELUARGA DI DESA SEPATIN KECAMATAN ANGGANA KABUPATEN KUTAI KARTANEGARA
}

\author{
Arbanah Saidi, S.Sos., M.Si \\ Drs.M.Z.Arifin, M.Si
}

\begin{abstract}
ABSTRAK
Potret Partisipasi Perempuan dalam meningkatkan Kesejahteraan Keluarga Di Desa Sepatin Kecamatan Anggana Kabupaten Kutai Kartanegara. Masyarakat Nelayan Desa Sepatin adalah masyarakat yang tinggal/bermukim di daerah pesisir pantai dan kehidupannya sehari-harinya tergantung pada sumber daya maritim yaitu sebagai pencari ikan.
\end{abstract}

Tujuan penelitian ini menggambarkan kehidupan keluarga nelayan Desa Sepatin, terutama berkaitan kegiatan suami (nelayan) dan partisipasi perempuan/isteri nelayan (gender), dalam menunjang perekonomian keluarga.

Fokus penelitian adalah aktivitas/kegiatan nelayan dan partisipasi /perempuan (gender) dalam meningkatkan kesejahteraan keluarga nelayan Desa Sepatin Kecamatan Anggana Kabupaten Kutai Kartanegara.

Berdasarkan hasil penelitian dan analisis data dapat dijelaskan bahwa kegiatan masyarakat nelayan Desa Sepatin kehidupan sehari-harinya tergantung kepada suami sebagai pencari ikan yang hasilnya pluktualitif atau tidak menentu tergantung musim. Untuk menunjang perekonomian keluarga kaum perempuan/isteri nelayan ikut membantu suami dalam memperoleh pendapatan dengan cara bekerja sampingan, selain kewajiban mereka mengurus keluarga.

Kaum perempuan/isteri nelayan bekerja sampingan, yakni bekerja sebagai pedagang/warung, membuat ikan kering yang dijual secara eceran, namun hasil pendapatan mereka juga relatif rendah tidak bisa mencukupi kebutuhan keluarga sehari-hari.

Kata Kunci : Partisipasi Perempuan dalam meningkatkan Kesejahtera Keluarga.

\section{PENDAHULUAN}

\section{A. Latar Belakang}

Di Indonesia dalam hal memanfaatkan hasil laut (ikan) yang dilakukan oleh para nelayan khususnya yang berada di pesisir wilayah Kalimantan Timur, masih menggunakan peralatan yang sederhana dengan segala keterbatasan karena modal usaha yang terbatas.

Dalam pengelolaan hasil laut, masyarakat nelayan di pesisir wilayah Kalimantan Timur menggunakan sistem pembagian kerja antara laki-laki dan 
perempuan, dimana laki-laki sebagai kepala keluarga mencari nafkah di laut dan perempuan mengurus keluarga di rumah, ini merupakan pandangan masyarakat tradisional, di era modernisasi sekarang ini perempuan diberikan kesempatan yang seluas-luasnya untuk aktif dalam kegiatan sosial-ekonomi, baik untuk kepentingan rumah tangga maupun untuk kepentingan dinamisasi perekonomian lokal.

Begitu pula dengan masyarakat nelayan yang berada di Desa Sepatin Kecamatan Anggana Kabupaten Kutai Kartanegara, dimana kaum wanita dan anak-anak pada umur tertentu turut andil dalam menopang kelangsungan kehidupan mereka sehari-hari.

Dengan demikian, istri nelayan memiliki kedudukan dan peran ganda, yaitu sebagai seorang istri dan sekaligus ibu rumah tangga. Serta sebagai wanita membantu suami dalam meningkatkan pendapatan keluarga. Oleh sebab itu, pemerintah wajib memberikan perhatian lebih terhadap isteri-isteri nelayan.

Agar isteri-isteri nelayan lebih aktif berpartisipasi dalam meningkatkan kesejahteraan keluarga, maka diperlukan peran serta pemerintah melalui program pemberdayaan masyarakat. Berdasarkan hasil observasi di lapangan, diperoleh informasi bahwa peran pemerintah dalam pemberdayaan masyarakat (perempuan) belum maksimal sehingga menyebabkan rendahnya partisipasi perempuan/istri-istri nelayan dalam meningkat perekonomi keluarga.

\section{B. Permasalahan}

Dari latar belakang masalah yang dipaparkan diatas, perlu ada perumusan masalah agar penelitian lebih dapat mendalami fenomena masyarakat nelayan Desa Sepatin Kecamatan Anggana Kabupaten Kutai Kartanegara.

Adapun permasalahan yang akan diteliti oleh TIM peneliti adalah sebagai berikut: "Bagaimana partisipasi perempuan (gender) dalam meningkatkan kesejahteraan keluarga di Desa Sepatin Kecamatan Anggana Kabupaten Kutai Kartanegara?".

\section{Tujuan Penelitian}

Tujuan yang diharapkan dari penelitian ini secara bertahap meliputi:

1. Untuk mendeskripsikan partisipasi perempuan (gender) dalam meningkatkan kesejahteraan keluarga di Desa Sepatin Kecamatan Anggana Kabupaten Kutai Kartanegara. Sehingga hasil penelitian ini dapat dijadikan bahan/dokumen/isu perempuan nelayan dalam riset lanjutan.

2. Memberikan rekomendasi kepada pemerintah Kabupaten Kutai Kartanegara untuk lebih memberikan perhatian kepada para perempuan (gender) di Desa Sepatin dalam hal pengembangan perekonomian keluarga. 


\section{Manfaat Penelitian}

1. Sebagai sumbangan pemikiran bagi pihak-pihak yang terkait khususnya Pemerintah Kabapaten Kutai Kartanegara.

2. Untuk mendapatkan gambaran yang jelas tentang partisipasi perempuan (gender) /istri-istri nelayan di Desa Sepatin Kecamatan Anggana Kabupaten Kutai Kartanegara

\section{LANDASAN TEORI}

\section{A. Partisipasi Perempuan (Gender)}

Pengertian partisipasi secara umum dapat ditangkap dari istilah partisipasi adalah, keikut sertaan seseorang atau sekelompok anggota masyarakat dalam suatu kegiatan.

Partisipasi didefinisikan sebagai keterlibatan mental dan emosi orangorang dalam situasi kelompok yang mendorong mereka untuk menyumbangkan pada tujuan kelompok dan sama-sama bertanggungjawab terhadapnya (dalam Abu Hurairah 2011 : 109).

Menurut Julia Clevs Mosse, Gender adalah seperangkat peran yang, seperti hal kostum dan topeng di teater, menyampaikan kepada orang lain kita adalah feminim atau maskulin. Perangkat perilaku khusus ini yang mencakup penampilan, pakaian, sikap, keperibadian, bekerja di dalam dan di luar rumah tangga, seksualitas, tanggungjawab keluarga dan sebagainya secara bersamasama memoles "peran gender kita". (2007: 3).

Fakih (2006 : 71) mengemukakan bahwa gender merupakan suatu sifat yang melekat pada kaum laki-laki maupun perempuan yang dikonstruksikan secara sosial maupun kultural.

Dengan demikian dapat disimpulkan bahwa gender adalah dianggap sebagai batasan atau pemisahan antara kaum wanita dan laki-laki dalam keluarga, tapi tujuannya untuk mentransformasikan hubungan kekeluargaan dan peran wanita dalam masyarakat. Bukan pula memisahkan anak-anak dari keluarga. Kesejahteraan dan kebahagiaan anak-anak datang dari kesejahteraan dan kebahagiaan keluarga dalam masyarakat.

\section{B. Kesejahteraan Keluarga}

Kesejahteraan adalah hal atau keadaan sejahtera, aman, selamat, dan tentram (dalam Dekdinas 2001 : 1011). Selanjutnya Konsep kesejahteraan menurut Nasikun (1996) dapat dirumuskan sebagai padanan makna dari konsep martabat manusia yang dapat dilihat dari empat indikator 1. Rasa Aman. 2. Kesejahteraan. 3. Kebebasan. 4. Jati diri.

Pengertian keluarga adalah suatu kelompok yang terdiri dari 2 orang atau lebih yang direkat oleh ikatan darah, perkawinan, atau adopsi serta tinggal bersama (dalam Hendi Suhendi dan Ramdani Wahyu, 2001 : 41).

Sedangkan pengertian "Keluarga sejahtera adalah Keluarga yang dibentuk berdasarkan perkawinan yang sah, mampu memenuhi kebutuhan 
hidup spiritual dan materi yang layak, bertaqwa kepada Tuhan Yang Maha Esa, memiliki hubungan yang selaras, serasi, dan seimbang antar anggota dan antar keluarga dengan masyarakat dan lingkungan”. (BKKBN, 1994:5).

Selanjutnya arti keluarga adalah merupakan kelompok primer yang paling penting didalam masyarakat. Keluarga merupakan sebuah group yang terbentuk dari perhubungan laki-laki dan wanita, perhubungan mana sedikit banyak berlangsung lama untuk menciptakan dan membesarkan anak-anak. Jadi keluarga dalam bentuk yang murni merupakan satu kesatuan sosial yang terdiri dari suami, isteri dan anak-anak yang belum dewasa. (Abu Ahmadi, 2007 : 221).

\section{Keluarga Nelayan}

Nelayan adalah orang yang mata pencahariannya melakukan penangkapan ikan. (Departemen Kelautan dan Perikanan, 2002). Selanjutnya pengertian nelayan menurut Wikipedia Indonesia, Nelayan adalah istilah bagi orang-orang yang sehari-harinya bekerja menangkap ikan, atau hewan laut lainnya yang hidup didasar, maupun permukaan perairan. Pengertian Nelayan menurut UU No. 45 Tahun 2009, nelayan adalah orang yang mata pencahariannya melakukan penangkapan ikan.

Dari uraian tersebut diatas dapat disimpulkan, yaitu keluarga lembaga sosial resmi yang terbentuk setelah adanya perkawinan. Sedangkan nelayan sebagai pekerja, yaitu orang-orang secara aktif melakukan kegiatan menangkap ikan, baik secara langsung maupun tidak langsung sebagai mata pencahariannya.

\section{METODOLOGI}

\section{A. Pendekatan Penelitian}

Penelitian ini menggunakan pendekatan deskriptif kualitatif terhadap partisipsi perempuan (gender) dalam meningkatan kesejahteraan keluarga di Desa Sepatin Kecamatan Anggana Kabupaten Kutai Kartanegara Provinsi Kalimantan Timur dimana seorang ibu turut berperan.

Metode penelitian kualitatif sering disebut metode penelitian naturalistik karena penelitiannya dilakukan pada kondisi yang alamiah (natural setting); disebut juga sebagai metode etnografi, karena pada awalnya metode ini lebih banyak digunakan untuk penelitian bidang antropologi budaya; disebut sebagai metode kualitatif, karena data yang terkumpul dan analisisnya lebih bersifat kualitatif. (Sugiyono, 2012:8).

\section{B. Fokus Penelitian}

Dalam penelitian yang menjadi Fokus adalah berikut:

1. Jenis Pekerjaan yang ditekuni

2. Partsipasi Isteri/Perempuan (gender)

3. Bantuan Pihak Pemerintah

\section{Populasi dan Sampel}


Tujuan penelitian ini adalah untuk menggambarkan fenomena nelayan Desa Sepatin. Sedangkan yang menjadi populasi dalam penelitian adalah penduduk Desa Sepatin yang berjumlah 653 nelayan, mengingat populasi cukup besar maka dilakukan penarikan sampel teknik sampling insidental. Artinya peneliti akan memberikan kuesioner kepada masyarakat yang pada saat itu ditemui di lokasi penelitian dan sekaligus akan mewancarainya untuk memperoleh data yang diperlukan dalam penelitian yang peneliti lakukan.

\section{Sumber Data}

1. Key Informan, yang menjadi Key Informan dalam penelitian ini adalah Kepala Desa Sepatin.

2. Informan dalam penelitian ini adalah nelayan Desa Sepatin yang berada di Dusun Sepatin dengan menggunakan teknik sampling insidental.

\section{E. Teknik Pengumpulan Data}

Untuk pengumpulan data sesuai dengan kebutuhan analisis deskriptif kualitatif, sebagai berikut.

a. Observasi yaitu pengamatan langsung ke lapangan (tempat) objek penelitian Dusun Sepatin Kecamatan Anggana.

b. interview yaitu mengumpulkan data dengan cara tanya jawab langsung dengan masyarakat nelayan dan Aparat Desa Sepatin Kecamatan Anggana.

c. Dokumentasi, yaitu pengumpulan bahan-bahan berupa catatan, data arsip, buku-buku pedoman yang berhubungan dengan fenomena kehidupan nelayan.

d. Kuesioner yaitu peneliti membuat daftar pertanyaan kemudian membagikannya kepada responden untuk diisi.

\section{F. Teknik Analisis Data}

Menurut Bogdan mengatakan "Analisis data adalah proses mencari dan menyusun secara sistimatis data yang diperoleh dari hasil wawancara, catatan lapangan, dan bahan-bahan lain, sehingga dapat mudah dipahami, dan temuannya dapat diinformasikan kepada orang lain ( Bogdan dalam Sugiyono, 2014 : 332).

Untuk menganalisis data yang diperoleh dari hasil penelitian ini, digunakan teknik analisis kuantitatif dengan menggunakan prosentase, atau dengan kata lain menggunakan teknik deskriptif kuantitatif dengan rumusan:

Rumus :

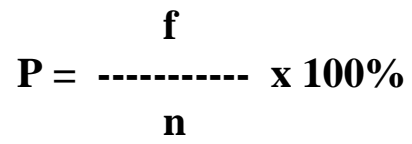

\section{Uber Silalahi (2012:348)}

\section{Keterangan :}

$\mathrm{P} \quad=$ Prosentase

$\mathrm{f} \quad=$ Frekuensi

$\mathrm{n} \quad=$ Kategori variasi 


\section{HASIL PENELITIAN DAN ANALISIS DATA}

\section{A. Gambaran Umum Objek Penelitian}

Desa Sepatin dengan luas wilayah 55,815 Ha, adalah desa yang merupakan bagian integral dari delapan (8) desa definitif yang ada di wilayah Kecamatan Anggana. Desa Sepatin terdiri dari tiga (3) dusun yaitu Dusun Sepatin sebagai Pusat Pemerintahan yang terdiri dari 5 Rukun Tetangga, Dusun Tanjung Berukang terdiri dari 5 Rukun Tetangga dan Dusun Bannati terdiri dai 3 Rukun Tetangga. Jumlah penduduk Desa Sepatin berjumlah 4.649 yang tersebar di 13 Rukun Tetangga, penduduk sepatin mayoritas bekerja sebagai nelayan.

Pemerintahan Desa Sepatin mempunyai letak yang strategis dengan batas-batas wilayah sebagai berikut :
Sebelah Utara
: Berbatasan dengan Desa Muara Pantuan
Sebelah Selatan
: Berbatasan dengan Kelurahan Muara Jawa
Sebelah Barat
: Berbatasan dengan Desa Kutai Lama
Sebelah Timur
: Berbatasan dengan Selat Makassar

Wilayah administrastif Desa Sepatin Kecamatan Anggana Kabupaten

Kutai Kartanegara yang terdiri dari dataran rendah serta meliputi area perusahaan asing yaitu Total E\&P Indonesie yang melakukan eksplorasi minyak dan gas. Sebagaimana desa-desa di wilayah Indonesia lainnya. Desa Sepatin Kecamatan Anggana Kabupaten Kutai Kartanegara mempunyai iklim subtropis dan terbagi dalam dua musim yaitu musim hujan dan musim kemarau.

Penduduk Desa Sepatin Kecamatan Anggana Kabupaten Kutai Kartanegara tergolong masyarakat yang heterogen, yang menunjukan pola kehidupan pembaharuan atau asimilasi karena ada beberapa suku terdapat di Desa Sepatin Kecamatan Anggana Kabupaten Kutai Kartanegara ini.

\section{B. Hasil Penelitian Lapangan}

Dalam penelitian ini, peneliti melakukan observasi dan wawancara dengan masyarakat nelayan di Dusun Sepatin dan melakukan penyebaran kuesioner kepada 33 orang responden sebagai informan yang dianggap dapat memberikan informasi yang relevan mengenai kehidupan, aktifitas mereka sebagai nelayan. Hasil wawancara dengan key informan yaitu: Sekretaris Desa Sepatin (Bapak Amrullah) megatakan sebagai berikut: "Masyarakat di Desa Sepatin mayoritas adalah nelayan dan bertempat tinggal di daerah pesisir pantai.

Dari penghasilan mereka hanya cukup untuk memenuhi kebutuhan keluarga sehari-hari, namun di Dusun Sepatin ini peran perempuan juga ada, dimana mereka berkerja sebagai pembersih ikan dan udang yang diperoleh para nelayan kemudian, dikumpulkan kepada pengepul. Tidak hanya itu saja pekerjaan yang isteri nelayan lakukan, namun juga ada yang mengolah hasil 
tangkapan ikan menjadi kerupuk (usaha mandiri), ikan kering dan petis. Penghasilan yang mereka dapat juga belum mencukupi kebutuhan keluarga”.

\section{Analisis Data}

Untuk menganalisis data yang diperoleh dari hasil penelitian, teknik analisis yang digunakan adalah analisis deskriptif kuantitatif, yang tujuannya adalah untuk mengungkapkan data tentang keluarga nelayan dalam partisipasi perempuan (gender).

\section{Jenis pekerjaan}

Untuk mengetahui pekerjaan yang ditekuni nelayan pada saat ini, diperoleh perhitungan data yang dari tabel 6 tersebut diatas diperoleh gambaran bahwa dari 33 orang responden (100\%), Nelayan mengatakan bahwa aktivitas sekarang bekerja mereka adalah menjadi nelayan.

Untuk mengetahui apa alasan responden memilih pekerjaan sebagai nelayan. Diperoleh perhitungan data jawaban dari responden (nelayan) adalah sebagai berikut : dari 33 orang responden (nelayan), ada 23 orang responden $(69,69 \%)$ mengatakan bahwa alasan mereka memilih pekerjaan nelayan adalah faktor keturunan, 10 orang responden $(30,31 \%)$ mengatakan mereka bekerja sebagai nelayan karena keinginan sendiri.

Selanjutnya untuk mengetahui kepemilikan alat penangkap ikan yang mereka (nelayan) miliki. Berdasarkan tabel 9 tersebut diatas yaitu dari 33 orang responden, Diperoleh perhitungan jawaban, ada 22 orang responden $(66,67 \%)$ mengatakan alat penangkap ikan yang mereka gunakan adalah milik sendiri, 11 orang responden $(33,33 \%)$ mengatakan alat penangkap ikan yang mereka gunakan adalah dengan cara menyewa dari orang lain.

\section{Peralatan yang digunakan pada saat melaut.}

Selanjutnya mengetahui Peralatan apa yang nelayan gunakan dalam menangkap ikan setiap harinya. Berdasarkan tabel 10 tersebut diatas diperoleh perhitungan jawaban dari 33 orang responden (Nelayan) adalah sebagai berikut, 32 orang responden $(96,97 \%)$ mengatakan bahwa mereka dalam menangkap ikan mempergunakan jaring ikan, dan 1 orang responden (3.03\%) dalam menangkap ikan menggunakan pancing atau kail.

Selanjutnya untuk mengetahui mengapa nelayan menggunakan peralatan penangkapan ikan dengan jaring dan pancing. Diperoleh jawaban dari 33 responden sebagai berikut, dari tabel 11 tersebut diatas diperoleh perhitungan bahwa dari 33 responden (nelayan), ada 32 orang responden $(39.39 \%)$ mengatakan alat penangkapan yakni Jaring dan Kail mudah digunakan, dan 20 orang responden $(60,61 \%)$ mengatakan Jaring dan Kail mudah didapatkan dipasar. 


\section{Masa melaut dan hasil yang didapat}

Selanjutnya untuk mengetahui apakah nelayan mencari ikan tergantung musim. Dari tabel 12 tersebut diatas diperoleh perhitungan bahwa dari 33 responden (nelayan), ada 30 orang responden (90.91\%) mengatakan bahwa mereka dalam menangkap ikan dilaut tergantung musim, dan 3 orang responden $(9,09 \%)$ mengatakan mereka dalam menangkap tidak tergantung musim.

Selanjutnya untuk mengetahui hasil tangkapan ikan yang melimpah. Dari tabel 13 tersebut diatas diperoleh perhitungan jawaban 33 responden (Nelayan), ada 12 orang responden (36,36\%) mengatakan bahwa hasil tangkapan ikan dapat mencukupi kebutuhan keluarga sehari-hari, dan 21 orang responden $(63,64 \%)$ mengatakan hasil tangkapan ikan kurang mencukupi kebutuhan keluarga sehari-hari.

Selanjutnya untuk mengetahui data hasil penjualan ikan yang diperoleh nelayan. Diperoleh perhitungan jawaban dari 33 responden adalah sebagai berikut. Dari tabel 14 tersebut diatas diperoleh perhitungan, ada 23 orang responden $(69.70 \%)$ mengatakan bahwa hasil penangkapan ikan dijual di penampungan, dan 10 orang responden $(30,30 \%)$ mengatakan hasil penangkapan ikan dijual kepada tengkulak.

Selanjutnya untuk mengetahui hasil tangkapan ikan yang diperoleh apakah dijual seluruhnya atau ada yang disisihkan untuk diolah sendiri (diolah secara mandiri). Dari tabel 15 tersebut diatas diperoleh perhitungan bahwa dari 33 responden (nelayan), ada 13 orang responden $(39,39 \%)$ mengatakan bahwa hasil tangkapan ada diolah sendiri untuk dijadikan ikan kering, kerupuk ikan, dan 20 orang responden $(60,61 \%)$ mengatakan hasil tangkapan tidak di olah (semua dijual di penampungan atau tengkulak).

Selanjutnya untuk mengetahui data aktivitas/kegiatan nelayan pada masa pakceklik (musim gelombang) dan nelayan tidak melaut. Diperoleh data jawaban dari 33 orang responden adalah sebagai berikut. Dari tabel 16 tersebut diatas diperoleh perhitungan dari 33 orang responden $(100 \%)$, nelayan mereka mengatakan tidak melaut atau tidak mencari ikan. Semua nelayan berada dirumah memperbaiki alat penangkapan ikan (jaring) dan memperbaiki peralatan yang berkaitan dengan mesin kapal. Sedangkan untuk memenuhi kebutuhan keluarga sehari-hari isteri mereka bekerja sampingan.

Selanjutnya untuk mengetahui data yang berkaitan dengan tanggapan suami (nelayan) tentang keterlibatan kaum perempuan (gender) atau isteri dalam meningkatkan kesejahteraan keluarga.

Diperoleh perhitungan dari 33 orang responden (Dari tabel 17) tersebut, ada 30 orang responden $(90,91 \%)$ mengatakan setuju, 1 orang 
responden $(3,03 \%)$ mengatakan kurang setuju dan 2 orang responden $(6,06 \%)$ mengatakan tidak setuju. Jika diperhatikan bahwa nelayan ssetu isterinya mencari pendapatan sampingan (bekerja untuk memperoleh pendapat keluarga).

Untuk mengetahui penghasilan nelayan perbulan. Dari 33 orang responden (Nelayan) diperoleh perhitungan jawaban responden, ada 23 orang responden $(69,70 \%)$ mengatakan penghasilan mereka perbulan 500.000 rupiah, 8 orang responden $(24,24 \%)$ mengatakan penghasilan mereka perbulan 1000.000 rupiah dan 2 orang responden $(6,06 \%)$ mengatakan penghasilan mereka 1.500 .000 rupiah. Jelas penghasilan nelayan belum memadai atau belum mencukupi kebutuhan hidup. Untuk itu keikut sertaan isteri dalam membantu suami untuk memperoleh pendapatan kelurga sangat dibutuhkan.

\section{Partisipasi Isteri/perempuan (gender)}

Isteri nelayan tentunya memiliki andil yang sangat besar dalam mendukung kelangsungan hidup keluarga nelayan, dimana mereka tidak hanya sebagai ibu rumah tangga namun mereka juga membantu suami dalam mempersiapkan kebutuhan suami untuk melaut atau menangkap ikan serta memperoleh pendapatan dengan cara bekerja sampingan.

Untuk mengetahui partisipasi isteri nelayan (gender). Diperoleh perhitungan jawaban dari 33 orang responden, ada 31 orang responden (93,94\%) mengatakan isteri ikut membantu mempersiapkan perlengkapan menangkap ikan kelaut, dan 2 orang responden $(6,06 \%)$ mengatakan isteri tidak ikut membantu mempersiapkan perlengkapan menangkap ikan dilaut.

Selanjutnya untuk memperoleh data tentang keikut sertaan keluarga dalam membantu suami dalam mempersiapkan peralatan penangkapan ikan dilaut. Dari tabel 19 tersebut diatas, dari 33 orang responden diperoleh perhitungan ada 32 orang responden $(96,97 \%)$ mengatakan keluarga selalu membantu mempersiapkan peralatan penangkapan ikan dan 1 orang responden $(3,03 \%)$ mengatakan keluarga tidak membantu mempersiapkan perlengkapan ikan.

Selanjutnya untuk mengetahui berapa jam isteri nelayan membantu suami mempersiapkan peralatan dan perlengkapan untuk menangkap ikan dilaut. Diperoleh perhitungan jawaban dari 33 orang responden adalah sebagai berikut, ada 32 orang responden $(96,97 \%)$ mengatakan waktu yang dibutuhkan membantu suami dalam mempersiapkan peralatan dan perlengkapan menangkap ikan dilaut membutuhkan waktu satu jam, dan 1 orang responden $(3,03 \%)$ mengatakan waktu yang dibutuhkan membantu suami dalam mempersiapkan peralatan dan penangkapan ikan dilaut membutuhkan waktu dua jam. 
Selanjutnya untuk mengetahui partisipasi isteri memperoleh pendapatan/penghasilan keluarga. Dari tabel 21 tersebut diatas diperoleh perhitungan dari 33 orang responden, ada 11 orang responden $(33,33 \%)$ mengatakan dalam memenuhi kebutuhan (pendapatan) keluarga isteri ikut bekerja, sebanyak 17 orang responden $(51,52 \%)$ mengatakan dalam memenuhi kebutuhan (pendapatan) keluarga kadang-kadang isteri bekerja kadang-kadang tidak, dan 5 orang responden $(15,15 \%)$ menagatakan mereka tidak bekerja.

Selanjutnya untuk mengetahui perolehan modal usaha isteri nelayan. Diperoleh jawaban dari 33 orang responden adalah sebagai, ada 8 orang responden $(24,24 \%)$ mengatakan berusaha dengan modal sendiri, 24 orang responden $(72,73 \%)$ mengatakan mereka memperoleh modal dari orang lain, dan 1 orang responden $(3,03 \%)$ mengatakan modal usaha diperoleh dari pemerintah.

Selanjutnya untuk mengetahui data tentang waktu kerja isteri dalam bekerja untuk membantu perekonomian keluarga. Diperoleh jawaban dari 33 responden adalah sebagai berikut, ada 2 orang responden $(6,06 \%)$ mengatakan mereka bekerja dari jam 08.00 pagi s/d 12.00 Siang, 4 orang responden $(12,12 \%)$ mengatakan dari jam 08.00 pagi s/d 16.00 Sore, dan 27 orang responden $(81,82 \%)$ mengatakan mereka bekerja dari jam 13.00 siang s/d 20.00 Malam.

Selanjutnya untuk mengetahui frekuensi kerja isteri nelayan. Dari 33 jawaban dari 33 orang responden diperoleh perhitungan data adalah sebagai berikut, ada 29 orang responden (87,88\%) mengatakan mereka (Isteri Nelayan) bekerja setiap hari, 3 orang responden $(9,09 \%)$ mereka (Isteri Nelayan) mengatakan kadang-kadang bekerja dan kadang-kadang tidak, 1 orang responden (3,03\%) mereka (Isteri Nelayan) mengatakan tidak bekerja.

Selanjutnya untuk mengetahui apakah hasil yang diperoleh isteri nelayan dapat mencukupi kebutuhan keluarga. Dari 33 orang responden, (Tabel 26), ada 7 orang responden (21,21\%) mengatakan bahwa penghasilan yang mereka peroleh dapat mencukupi kebutuhan keluarga, 24 orang responden $(72,73 \%)$ mengatakan penghasilan mereka kurang mencukupi kebutuhan keluarga, dan 2 orang responden $(6,06 \%)$ mengatakan penghasilan mereka tidak mencukupi kebutuhan keluarga.

Selanjutnya untuk mengetahui siapa yang menjaga anak pada saat ibu dan suami bekerja. Diperoleh jawaban dari 33 orang responden (Tabel 27) adalah sebagai berikut, ada 1 orang responden $(3,03 \%)$ mengatakan pada saat mereka bekerja anak-anak dititipkan kepada tetangga, 3 orang responden $(9,09 \%)$ mengatakan anak-anak mereka dibawa ke tempat bekerja, dan 29 orang responden $(87,88 \%)$ mengatakan pada saat bekerja anak-anak mereka ditinggal bersama saudaranya di rumah. 
Selanjutnya untuk mengetahui data tentang tanggapan para ibu mengenai anak mereka yang ikut membantu bekerja. Diperoleh jawaban dari 33 orang responden responden adalah sebagai berikut, ada 24 orang responden $(72,73 \%)$ mengatakan bahwa anak-anak mereka ikut membantu memperoleh penghasilan keluarga (bekerja), 4 orang responden $(12,12 \%)$ mengatakan bahwa anak-anak mereka kadangkadang bekerja dan kadang-kadang tidak, dan 5 orang responden $(15,15$ \%) mengatakan bahwa anak-anak mereka tidak bekerja.

Selanjutnya untuk mengetahui tanggapan orang tua tentang keikut sertaan anak dalam membantu menambah penghasilan keluarga. Diperoleh jawaban dari 33 orang responden adalah sebagai berikut, ada 10 orang responden $(30,30 \%)$ mengatakan mereka setuju anak-anak mereka ikut membantu menambah penghasilan keluarga, 19 orang responden $(57,58 \%)$ mengatakan mereka kurang setuju jika anak mereka membantu menambah penghasilan keluarga, dan 4 orang responden $(12,12 \%)$ mereka mengatakan tidak setuju bila anak-anak mereka membantu menambah penghasilan keluarga.

Selanjutnya untuk mengetahui penghasilan isteri nelayan perbulan dalam membantu menambah penghasilan keluarga. Diperoleh jawaban dari 33 orang responden adalah sebagai berikut, ada 27 responden $(81,82 \%)$ mengatakan pengahsilan satu bulan 500 ribu rupiah dan 6 orang responden $(18,18 \%)$, mengatakan penghasilan mereka satu bulan 1.000.000 rupiah.

\section{Bantuan Pihak Pemerintah Kabupaten Kutai Kartanegara}

Masyarakat nelayan Desa Sepatin merupakan bagian Warga Negara Indonesia yang berhak memperolah bantuan dari pemerintah khususnya Pemerintah Kabupaten Kutai Kartanegara. Bantuan yang diberikan oleh Pemerintah dalam rangka untuk membantu usaha nelayan.

Untuk mengetahui bantuan yang pernah diberikan oleh Pemerintah Kabupaten Kutai Kartanegara kepada Desa Sepatin. Diperoleh jawaban dari 33 orang responden adalah sebagai berikut, ada 14 orang responden $(42,42 \%)$ mengatakan pernah mendapat bantuan dari Pemerintah Kabupaten Kutai Kartanegara, dan 19 orang responden $(57,58 \%)$ mengatakan tidak pernah mendapat bantuan dari Pemerintah Kabupaten Kutai Kartanegara.

Selanjutnya untuk mengetahui bentuk bantuan yang pernah diberikan oleh Pemerintah Kabupaten Kutai Kartanegara kepada masyarakat nelayan Desa Sepatin untuk meningkatkan penghasilan. Diperoleh jawaban dari 33 orang responden adalah sebagai berikut, ada 10 orang responden $(30,30 \%)$ mengatakan bantuan yang diberikan oleh Pemerintah Kabupaten Kutai Kartanegara dalam bentuk peralatan menangkap ikan, 4 orang responden $(12,12 \%)$ mengatakan bantuan yang diberikan dalam bentuk modal usaha, dan 19 orang responden $(57,58 \%)$ 
mengatakan tidak pernah mendapat bantuan dari Pemerintah Kabupaten Kutai Kartanegara.

Selanjutnya untuk mengetahui kesesuaian bantuan yang diberikan dengan keperluan penangkapan ikan. Diperoleh jawaban dari 33 orang responden adalah sebagai berikut, ada 6 orang responden $(18,18 \%)$ mengatakan bahwa bantuan peralatan penangkapan ikan yang diberikan sudah sesuai dengan keperluan penangkapan ikan, 20 orang responden $(60,61 \%)$ mengatakan kurang sesuai dan 7 orang responden $(21,21 \%)$ mengatakan tidak sesuai.

Selanjutnya untuk mengetahui cara mendapatkan bantuan peralatan penangkapan ikan dari Pemerintah Kabupaten Kutai Kartanegara. Dipeoleh jawaban dari 33 orang responden adalah sebagai berikut, ada 6 orang responden $(18,18 \%)$ mereka mengatakan bahwa untuk mendapatkan bantuan mereka mengusulkan melalui kelompok nelayan dan 27 orang responden $(81,82 \%)$ mereka mengatakan untuk mendapatkan bantuan mereka mengusulkan dengan secara mandiri.

\section{P E N U T U P}

\section{A. Kesimpulan}

Dari hasil penelitian Potret Kehidupan Nelayan dan Partisipasi Isteri nelayan di Dusun Sepatin Kecamatan Anggana Kabupaten Kutai Kartanegara, dapat simpulkan bahwa :

1. Masyarakat nelayan di Dusun Sepatin rata-rata merupakan nelayan keturunan dan menggunakan sarana dan prasarana penangkapan ikan yang masih sederhana/tradisional serta tergantung kepada cuaca/musim serta penghasilan mereka tidak menentu.

2. Sikap para nelayan terhadap keikut sertaan isteri dalam mencari nafkah untuk membantu perekonomian keluarga cukup baik hal ini dibuktikan dengan diberikannya kesempatan kepada isteri nelayan untuk kerja sampingan.

3. Bantuan peralatan untuk menangkap ikan di laut yang diberikan oleh Pemerintah Kabupaten Kutai Kartanegara selama ini belum sepenuhnya dapat dirasakan oleh masyarakat nelayan Desa Sepatin Kecamatan Anggana Kabupaten Kutai Kartanegara.

\section{B. Saran}

1. Untuk meningkat hasil takapan ikan nelayan di Desa Sepatin, hendaknya Pemerintah Kabupaten Kutai Kartanegara lebih tanggap terhadap kebutuhan fasilitas penangkapan ikan yang dikehendaki oleh masyartakat nelayan dan masih perlu pengkajian lebih lanjut.

2. Untuk isteri nelayan khusunya nelayan di Desa Sepatin perlu diberikan pengetahuan dan pelatihan praktis tentang bagaimana mengelola hasil tangkapan ikan, sehingga dapat meningkatkan pendapat keluarga 
sekaligus mengatasi perekonomian keluarga. Dan masih memerlukan pengkajian lebih lanjut mengenai keterampilan apa yang cocok untuk para isteri nelayan.

3. Bantuan yang diberikan hendaknya bersifat fasiltas yang benardibutuhkan oleh para nelayan Desa Sepatin Kecamatan Anggana Kabupaten Kutai Kartanegara.

\section{DAFTAR PUSTAKA}

Anonim. Kamus Besar Bahasa Indonesia. Jakarta : Balai Pustaka.

Abu Ahmadi, 2007. Psikologi Sosial, Jakarta : Rineka Cipta.

Fakih, Mansur. 2006. Analisis Gender dan Transformasi Sosial. Yogyakarta : Pustaka Pelajar.

Huraerah, Abu. 2011. Pengorganisasian dan Pengembangan Masyarakat. Bandung : Humaniora.

Mosse, Cleves J. 2007. Gender dan Pembangunan. Yogyakarta : Rifka Annisa.

Sugiyono, 2007. Statistika untuk penelitian, Bandung, Alpabeta.

Sugiyono. 2012. Metode Penelitian Kuantitatif, Kualitatif dan $R$ \& D. Bandung: Alfabeta.

Sugiyono, 2014, Meode Penelitian Kombinasi (Mixed Methods), Bandung Alfabeta.

Silalahi, Uber. 2012. Metode Penelitian Sosial. Bandung : Aditama.

Sitorus, Henry. 2005. Menelusuri Kausa Ketertinggalan Masyarakat Pantai Dalam Isu-Isu Kelautan Dari Kemiskinan Hingga Bajak Laut. Jakarta : Pustaka Pelajar.

Suhendi, Hendi. 2001. Pengantar Studi Sosiologi Keluarga. Bandung : Pustaka Setia. Theresia, Aprilia. 2014. Pembangunan Berbasis Masyarakat. Bandung : Alfabeta.

\section{Dokumen}

Anonim, Undang-Undang Republik Indonesia Nomor 10 Tahun 1992 Tentang Perkembangan Kependudukan Dan Pembangunan Keluarga Sejahtera, Sejahtera, BKKBN, Jakarta, 1992.

BKKBN. 1994. Pembangunan Keluarga Sejahtera di Indonesia Berdasarkan UU No. 10 Tahun 1992 dan GBHN tahun 1993. Jakarta : Kantor Menteri Kependudukan / BKKBN.

\section{Internet}

Nasikun. 1993. "Urbanisasi dan Kemiskinan Di Dunia Ketiga”. Yogyakarta : Tiara Wacana. http://perencanaankota.blogspot.co.id//12/01/beberapa-konsep-tentangkesejahteraan-html/? $m=1$ diakses 17 November 2016.

Baron, A.R. 2000. "Psikologi Sosial. Bandung". Khasanah Intelektual. http://www.sarjanaku.com/2012/06/pengertian-gender-paraahli-html/?m=1 diakses 17 November 2016).

Setiawan. 2012-2016. Kesejahteraan.

http://kbbi.web.id/sejahtera. diakses 01 Desember. 


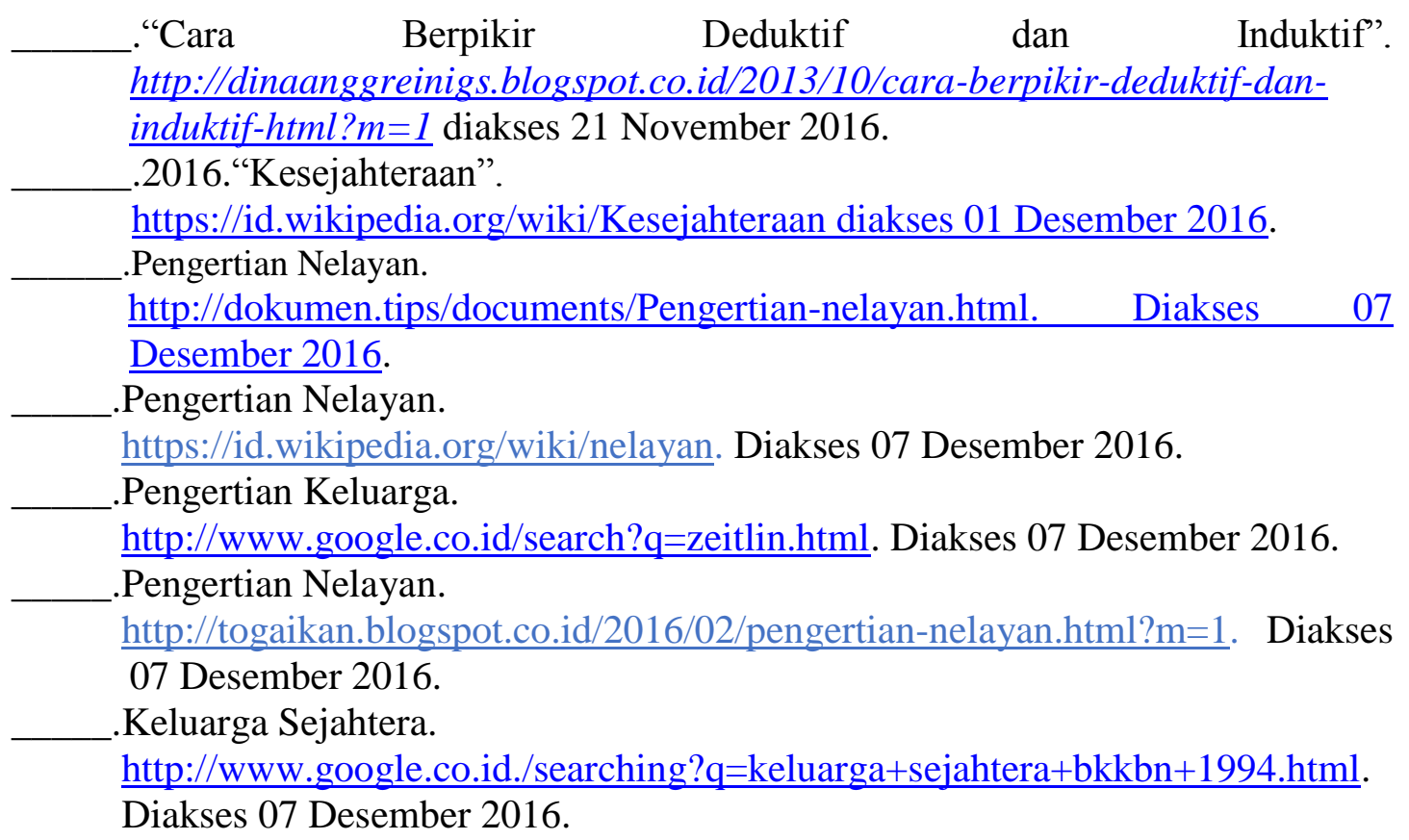

